\title{
Inter se modification of the UN drug control conventions
}

An exploration of its applicability to legitimise the legal regulation of cannabis markets

Draft - International Community Law Review

Abstract

Legal tensions are growing as more jurisdictions move towards legal regulation of the cannabis market, in clear contravention of the obligation of the UN drug control treaties to limit cannabis exclusively to medical and scientific purposes. Reaching a new global consensus to amend the conventions does not appear to be a viable political option in the foreseeable future. Amongst the limited options not requiring consensus, inter se modification-based on article 41 of the Vienna Convention on the Law of Treaties - appears to provide a useful safety valve for collective action to adjust a treaty regime arguably frozen in time. Restrictions imposed on inter se modification require that an agreement to derogate from certain cannabis treaty provisions include a clear commitment to the original treaty aim to promote the health and welfare of humankind and to the original treaty obligations vis-à-vis states not party to the agreement. A coordinated collective response has benefits compared to a chaotic scenario of multiple unilateral reservations and questionablere-interpretations.

Keywords

Cannabis, international drug control, Single Convention on Narcotic Drugs, Vienna Convention on the Law of Treaties, inter se modification 
The drug policy landscape is in a process of profound change since more and more countries are moving towards a legal regulation of the cannabis market. This reality is increasing legal tensions within the international drug control regime, based on the 1961 Single Convention on Narcotic Drugs ${ }^{1}$ and its 1972 Protocol $^{2}$ and supplemented with the 1971 Convention on Psychotropic Substances ${ }^{3}$ and the 1988 Convention against Illicit Traffic in Narcotic Drugs and Psychotropic Substances ${ }^{4}$. Article 4 of the Single Convention obliges all parties 'to limit exclusively to medical and scientific purposes the production, manufacture, export, import, distribution of, trade in, use and possession of drugs' placed under its control, and cannabis has been listed under its strictest control schedules. ${ }^{5}$

The International Narcotics Control Board (INCB or Board), the 'independent and quasijudicial expert body ${ }^{6}$ for monitoring compliance with the 1961 and 1971 drug control treaties, has condemned these steps as contrary to states' international obligations. In its Annual Report for 2016, for example, the INCB commented on Canada's intention to move to a regulated market for cannabis:

Canada is party to all three international drug control treaties. The Government has initiated a process that has as its goal the legalization and regulation of access to cannabis for non-medical use. The Board notes that the legalization of the use of cannabis for non-medical purposes is inconsistent with the provisions of the 1961 and 1988 Conventions because the Conventions oblige States parties to limit the use of narcotic drugs exclusively to medical and scientific purposes. That limitation, expressed in article 4, paragraph (c), of the 1961 Convention, is binding on all parties; regulating the use of drugs outside medical and scientific purposes is not allowed under the Convention. The limitation of the use of drugs to medical and scientific purposes is a fundamental principle that lies at the heart of the international drug control framework, to which no exception is possible and which gives no room for flexibility. The Board urges the Government to pursue its stated objectives - namely the promotion of health, the protection of young people and the decriminalization of minor, non- violent offenceswithin the existing drug control system of the Conventions. ${ }^{7}$

Canada's Foreign Minister Chrystia Freeland, in May 2018, indeed acknowledged that Bill C45 to regulate cannabis 'will result in Canada contravening certain obligations related to cannabis under the three UN drug convention'. ' 'I think we need to be open about that', she said, adding that the Canadian government is 'definitely open to working with treaty partners to identify solutions that accommodate different approaches to cannabis within the

\footnotetext{
${ }^{1}$ New York, 30 March 1961, 520 UNTS 151, in force 13 December 1964.

${ }^{2}$ Geneva, 25 March 1972, 976 UNTS 3, in force 8 August 1975.

${ }^{3}$ Vienna, 21 February 1971, 1019 UNTS 175, in force 16 August 1976.

${ }^{4}$ Vienna, 20 December 1988, 1582 UNTS 95, in force 11 November 1990.

${ }^{5}$ Cannabis, cannabis resin, and extracts and tincture of cannabis are in Schedule I among substances whose properties might give rise to dependence and that present a serious risk of abuse; cannabis and cannabis resin are also listed in Schedule IV, along with a few other selected substances from Schedule I that are deemed particularly dangerous and having extremely limited therapeutic value.

${ }^{6}$ International Narcotics Control Board (INCB), https://www.incb.org/incb/en/index.html

${ }^{7}$ INCB, Report of the International Narcotics Control Board for 2016, New York, United Nations (2017), para 223 , p.31. For similar remarks in regard to the adoption of similar schemes in other states parties see also (United States) para 198, p.29 and (Jamaica) para 415, p.55. Also see INCB, Report of the International Narcotics Control Board for 2017, New York, United Nations (2018), paras 185-187, p. 36.

${ }^{8}$ Chrystia Freeland, Minister of Foreign Affairs, The Standing Standing Committee on Foreign Affairs and International Trade (AEFA), Evidence, Ottawa, May 1, 2018. https://sencanada.ca/en/Content/Sen/Committee/421/AEFA/54008-e
} 
international framework.' ${ }^{9}$ The existing legal regulations at state level in the U.S. and in Uruguay are already clearly out of compliance with the provisions of the UN drug treaties, and as more nations like Canada contemplate this step, treaty tensions will continue to mount.

This article explores the option of an inter se agreement among like-minded parties for effecting compatibility of cannabis regulation with commitments under the UN drug control conventions. Article 41 of the 1969 Vienna Convention on the Law of Treaties (VCLT) ${ }^{10}$ provides for such agreements between two or more parties in order to modify a multilateral treaty like a drug convention. The VCLT, the 'treaty on treaties', ${ }^{11}$ was drafted by the International Law Commission (ILC), established by the General Assembly in 1947 to 'initiate studies and make recommendations for the purpose of ... encouraging the progressive development of international law and its codification'. ${ }^{12}$ According to one of the VCLT commentaries:

Due to the conflicting interests prevailing at an international level, amendments of multilateral treaties, especially amendments of treaties with a large number of parties, prove to be an extremely difficult and cumbersome process; sometimes, an amendment seems even impossible. It may thus happen that some of the States Parties wish to modify the treaty as between themselves alone. ${ }^{13}$

\footnotetext{
${ }^{9}$ Ibidem.

${ }^{10}$ Vienna, 23 May 1969, 1155 UNTS 331, in force 27 January 1980. Although the main topic of this piece is the legal effect of an inter se agreement among parties to Single Convention, which was concluded in 1961, eight years prior to the conclusion of the VCLT, in strictly formal terms the VCLT is not applicable because article 4 of the VCLT applies a principle of non-retroactivity, unless it crystallizes a rule that exists independently of the VCLT. Paul McDade, "The Effect of Article 4 of the Vienna Convention of the Law of Treaties 1969" International and Comparative Law Quarterly, Volume 35, (1986) p. 499, at p. 502, takes a formalistic view arguing that only provisions of the VLCT which are clearly declaratory of customary international law govern preexisting treaties. Oliver Dörr, Kirsten Schmalenbach, "Article 41. Agreements to modify multilateral treaties between certain of the parties only" in O. Dörr, and K. Schmalenbach (eds), Vienna Convention on the Law of Treaties, Springer-Verlag, Berlin and Heidelberg, 2012, p.719 at p.721 et seq note that while modification inter se was not an uncommon practice there were no common rules on the subject prior to the VCLT and thus article 41 did not codify an already existing rule of customary law. However, inter se modification was an isolated but growing reality by the time of the conclusion of the VCLT. Anne Rigaux and Denys Simon, Article 41: Agreements to Modify Multilateral Treaties Between Certain of the Parties Only, in: Olivier Corsten and Pierre Klein (eds), The Vienna Convention on the Law of Treaties: A Commentary, Vol. II, Oxford: Oxford University Press (2011), p. 986 at pp. 991 et seq explain that the absence of generalised jurisprudence on this matter was because inter se treaties had not given significant difficulties until the $20^{\text {th }}$ Century and they had only really surfaced as an issue with the rise of multilateral treaties. In a sense then, article 41 is a belated solution to an existing problem, although the substance of the article was already in evidence in article 22(b) of the Harvard Draft Convention on the Law of Treaties, American Journal of International Law, Vol. 29, Special Supplement (1935) p.1016. Shabtai Rosenne in "The Temporal Application of the Vienna Convention on the Law of Treaties" in Cornell International Law Journal, Volume 4, Issue 1 (1970), p. 1, a p.20 provides, we submit, the most practical way of approaching this conundrum because he dismisses the importance of article 4 , arguing that the VCLT largely consolidated customary internal law. At p. 19 he notes that the VCLT often provides a clearer and more effective definition of the customary law that it consolidates, and noting at p. 22 that only arid formalism would insist that a rule such as that contained in article 41 was not a "rule of international law" as anticipated in article 4 of the VCLT, applicable to a general dispute about a treaty. We would argue that given the scanty basis for practice in regard to inter se modification, those that deny article 41 is applicable, bear the burden of establishing it inapplicability.

${ }^{11}$ Anthony Aust, Vienna Convention on the Law of Treaties (1969), Max Planck Encyclopedia of Public International Law, June 2006. http://opil.ouplaw.com/view/10.1093/law:epil/9780199231690/law9780199231690-e1498

${ }^{12}$ Charter of the United Nations, article 13 (1) (a). See: http://legal.un.org/ilc/

${ }^{13}$ Oliver Dörr and Kirsten Schmalenbach, eds., Vienna Convention on the Law of Treaties: A Commentary, London and New York: Springer Heidelberg Dordrecht (2012), p. 719.
} 
Such an inter se modification agreement is permissible if (a) 'the possibility of such a modification is provided for by the treaty' or (b) when 'the modification in question is not prohibited by the treaty and (i) does not affect the enjoyment by the other parties of their rights under the treaty or the performance of their obligations; or (ii) does not relate to a provision, derogation from which is incompatible with the effective execution of the object and purpose of the treaty as a whole.' ${ }^{14}$

Before exploring these conditions for the operation of article 41, it should be noted that in terms of the rubric to article 41 such inter se agreements 'modify the treaty between themselves alone', i.e., they create a special regime but only for their parties. They do not alter the general regime, to which the parties to the inter se agreement remain bound and which they must respect 'in their relations with the other parties as if the inter se agreement did not exist." ${ }^{15}$ This rubric respects the pacta tertiis nec nocent nec prosunt rule of international law (treaties neither obligate nor benefit third parties) consolidated in article 34 of the VCLT that such agreements cannot create rights or impose obligations on other non- parties to the inter se agreement which are party to the drug conventions. Article 41 is designed to ensure that such agreements do not provide a back-door to amendment of the treaty as a whole in violation of this rule.

Most such modifications cause little difficulty because they are designed to 'implement, update and strengthen the treaty in the relations between the parties to the modifying treaty', ${ }^{16}$ i.e., to add to the rule, not to relax the rule. In deliberations on the draft version of article 41 the ILC clarified that 'a modification was not always necessarily the reversal of a rule in the amended instrument (amendment contra legem); the effect of the modification might be to add something that was consistent with that instrument (amendment secundum legem) or to remove doubts which had arisen (amendment praeter legem). ${ }^{17}$ Inter se agreements of the second kind (secundum or intra legem) are usually unproblematic. The Nuclear Non- Proliferation Treaty, ${ }^{18}$ for example, deliberately promotes the inter se mechanism to agree on stricter provisions among groups of countries, for example the creation of nuclear-free zones, than could be reached in the negotiations between all the parties. Modifications of this kind must meet the implicit double imperative of guaranteeing stability of general relations among the parties while enabling movement in special relations of certain parties. ${ }^{19}$

An inter se agreement on cannabis regulation would however clearly fall in the category of a contra legem modification. The preparatory work of the VCLT and subsequent discussions at the ILC leave no doubt that the inter se mechanism can also be used contra legem, to derogate from certain treaty provisions, something that might be seen as a 'collective reservation' by two or more of the parties (although it should be noted that there are subtle but important differences between the rules governing reservations and the rules governing inter se modification-see below at footnote 52), otherwise there would have been no need to specify the conditions regarding

\footnotetext{
${ }^{14}$ United Nations, Vienna Convention on the Law of Treaties, Vienna, May 23, 1969, United Nations Treaty Series 1155, no. 18232 (1980), article 41, paragraph 1.

${ }^{15}$ A/CN.4/L.682, Fragmentation of International Law: Difficulties arising from the Diversification and Expansion of International Law, Finalized by M Koskenniemi, International Law Commission (ILC 2006), para 305, p. 157.

${ }^{16}$ Ibid., para 297, p. 152.

17 International Law Commission (ILC), 'Summary Record of the 746th Meeting: 13 July 1964', A/CN.4/SR.764, in: Yearbook of the International Law Commission: 1964, vol. I (New York: UN, 1965), para 104, p. 274.

${ }^{18}$ Treaty on the Non-Proliferation of Nuclear Weapons, 1 July 1968, 729 UNTS 161; in force 5 March 1970.

${ }^{19}$ Suzanne Bastid, Les Traités dans la vie Internationale, (Paris: Economica, 1985), p.179.
} 
the rights of other parties and the object and purpose of a treaty. ${ }^{20}$

For like-minded states parties that have introduced domestically a legally regulated cannabis market for non-medical purposes, an inter se modification agreement would resolve the legal tension with certain cannabis-related provisions of the drug conventions. After derogating from those provisions by means of inter se modification-similar to the effect of a unilateral reservation - those states would no longer be in breach of their treaty obligations. They may, however, face a claim by other non-parties to the inter se agreement that are parties to the drug conventions that they have tried to modify their relationship with all parties. Evidence of 'the spill-over effect that legalization may have in neighbouring jurisdictions where the use of cannabis for non-medical purposes remains illegal ${ }^{21}$ might lend substance to this claim. But simple modification of the rule itself may already entitle such a response because it may affect, for example, reporting duties to the INCB. The Board administers a system of estimates for narcotic drugs, including cannabis, ${ }^{22}$ and monitors licit activities through a statistical returns system 'to ensure that adequate supplies of drugs are available for medical and scientific uses and that the diversion of drugs from licit sources to illicit channels does not occur. ${ }^{23}$ It is unclear whether the INCB and the regulating states parties would be willing to consider expanding the administrative system to include estimates and requirements of cannabis for other purposes that would become licit under an inter se agreement, but remain illicit under the UN convention for the other parties.

In the case of Bolivia's reservation on coca leaf, in fact the INCB in its latest Annual Report does invite the country 'to furnish to it separate estimates and statistical reports in respect of the reserved activities, in addition to the estimates and statistics mandatory under article 19, article 20 and article 27, paragraph 2, of the 1961 Convention as amended. These estimates and statistical reports should specify the quantities of coca leaf that are estimated to be used and actually used in the country for the reserved purposes. ${ }^{24}$ Similar separate estimates and statistics could be provided on non-medical and non-scientific purposes of cannabis allowed under an inter se agreement. The amended Single Convention only requires furnishing estimates and statistics for the licit cultivation of opium poppy. ${ }^{25}$ In the case of coca and

\footnotetext{
${ }^{20}$ While the conditions for the operation of reservations are spelled out in articles 19-21 of the VCLT, the ILC in its discussion about reservations specifically mentions that the same conditions basically apply to inter se modification, see A/CN.4/L.682, Fragmentation of International Law, (ILC 2006), op. cit., p. 159.

${ }^{21}$ INCB, Report of the International Narcotics Control Board for 2016, para 325, p. 42.

${ }^{22}$ According to the INCB, 'The licit use of cannabis has been increasing considerably since 2000. Before 2000, licit use was restricted to scientific research and was reported only by the United States. Since 2000, more and more countries have started to use cannabis and cannabis extracts for medical purposes, as well as for scientific research. In 2000, total licit production was 1.4 tons; by 2016 it had increased to 209.9 tons. ... In 2016, the United Kingdom was the main producer, with 95 tons (44.9 per cent of the total), followed by Canada, with 80.7 tons, mostly intended for domestic consumption. They were followed by Portugal (21 tons), Israel (9.2 tons), the Netherlands and Chile (both 1.4 tons)'. INCB, Report 2017, Estimated World Requirements for 2018 - Statistics for 2016, p. 43.

${ }^{23}$ INCB, Mandate and Functions, http://www.incb.org/incb/ en/about/mandate-functions.html

${ }^{24}$ INCB, Report of the International Narcotics Control Board for 2017, New York, United Nations (2018), para 144, pp. 31-32.

${ }^{25}$ The 1972 Protocol amending the 1961 Single Convention on Narcotic Drugs introduced the requirement to provide annual estimates of 'The area (in hectares) and the geographical location of land to be used for the cultivation of the opium poppy' in article 19(1)(e); and statistics on 'Ascertainable area of cultivation of the opium poppy' in article 20(1) (g). According to the Commentary, the wording 'ascertainable' was introduced to clarify that Parties need only make such efforts that 'can reasonably be expected of them': 'They are certainly not required to search out every little garden patch on which opium poppies are grown for decorative purposes'. Commentary on the Protocol Amending the Single Convention on Narcotic Drugs, 1961, Done at Geneva on 25 March 1972, United Nations (New York 1976), para 5, pp. 56-57.
} 
cannabis, only data on the harvested amounts - in kilogrammes - of coca leaf, cannabis buds and resin are required, not the amount or location of hectares cultivated. ${ }^{26}$ The provision of additional data on cannabis production for other licit purposes under a reservation or inter se agreement would not therefore need to include details on areas of cultivation.

A special system of non-prohibition of cannabis among some parties at a domestic level formalised in an inter se agreement appears to be impossible if those same states have promised a large number of other parties that they will maintain a general system of prohibition of cannabis for non-medical and non-scientific purposes, and the special system may necessitate changes to the general system. Analysis of the two additional conditions in article 41 shows how they are designed to constrain the actions of parties to reduce the risk of 'true incompatibility' between the general obligations - the drug conventions - and the special obligations - the inter se agreement - thus avoiding bringing into play article 30 of the VCLT's rules about incompatible successive treaty obligations. ${ }^{27}$ In other words, adherence to the conditions in article 41 avoids a situation of normative conflict where parties to an inter se agreement modify not only their relations among themselves but generally. This provokes the key question the rest of this article explores: can domestic cannabis reform which is harmonised among like-minded states by an inter se agreement and which may even permit international trade in cannabis among these parties, avoid unacceptable interference with the rights of nonparties to the inter-se agreement and avoid substantive incompatibility with the drug conventions?

\section{Balancing Treaty Stability and Change}

Article 41 has a Janus-faced quality in that it looks backward to maintaining stability of the treaty and forward to its modification for some parties so long as they do not disturb that stability. During the ILC deliberations on the VCLT, it was observed that with the adoption of a special article on inter se modification, the Commission 'had reached an ingenious compromise between the need to recognize the rights of the parties to a treaty in its initial form and the need to permit the modification of the treaty in order to take account of certain international requirements. But care should be taken to maintain flexibility so as to meet the requirements of the international community. ${ }^{28}$ The drafters of the VCLT considered the option of inter se modifications as a core principle for international law and the issue was discussed at length at the ILC in 1964: 'The importance of the subject needed no emphasis; it involved reconciling the need to safeguard the stability of treaties with the requirements of peaceful change. ${ }^{29}$ The words of U.S. Secretary of State Edward R. Stettinius Jr., head of the U.S. delegation to the 1945 San Francisco Conference at which the founding United Nations Charter was adopted, were repeated during the discussion in this regard in the ILC: 'Those who seek to develop procedures for the peaceful settlement of international disputes, always confront the hard task of striking a balance between the necessity of assuring stability and

\footnotetext{
${ }^{26}$ The INCB secretariat, however, in December 2014, adapted Part III(B) and (C) in the $18^{\text {th }}$ edition of Form C on Annual Statistics of Production, Manufacture, Consumption, Stocks and Seizures of Narcotic Drugs, adding columns for submitting data on hectares of licit cannabis and coca cultivation, without specifying that such information is requested on a voluntary basis, not as a treaty requirement.

${ }^{27}$ Anne Rigaux and Denys Simon, Article 41: Agreements to Modify Multilateral Treaties Between Certain of the Parties Only, in: Olivier Corsten and Pierre Klein (eds), The Vienna Convention on the Law of Treaties: A Commentary, Vol. II, Oxford: Oxford University Press (2011), pp.986-988.

${ }^{28}$ A/CN.4/SER.A/1966, Yearbook of the International Law Commission: 1966, Vol. I, Part I, 876 ${ }^{\text {th }}$ meeting, 23 June 1966, (ILC: New York, United Nations 1967), p. 219.

${ }^{29}$ A/CN.4/SR.745, "Summary Record of the 745 th Meeting: 15 June 1964", in: Yearbook of the International Law Commission: 1964, Vol. I (ILC: New York, United Nations 1965), para. 49, p. 144.
} 
security on the one hand and of providing room for growth and adaptation on the other. ${ }^{30}$

Merkouris and Fitzmaurice record that it was not disputed in the ILC that inter se agreements are 'an essential technique, and a necessary safety valve, for the adjustment of treaties to the dynamic needs of international society. If such a technique had not existed, there would have been stagnation in many treaty relations... The inter se procedure had been the means resorted to for that necessary evolution. ${ }^{31}$ The VCLT therefore needed to "make provision for the inter se procedure so as to avoid the stagnation that would result from the liberum veto of a single party'. ${ }^{32}$ From the very beginning, its evolutionary nature was seen as fundamental to the United Nations system, a system in which according to the Egyptian delegate all member states 'undertake to respect agreements and treaties to which they have become contracting parties without prejudice to the right of revision'. ${ }^{33}$ It was therefore 'equally important to ensure that arbitrary obstacles were not allowed to impede the process of change. There had been many instances in the past of States, by their stubborn refusal to consider modifying a treaty, forcing others to denounce it. ${ }^{34}$

That is precisely what happened after Bolivia adopted a new constitution in 2009 which required the state to protect the coca leaf as part of its cultural patrimony. ${ }^{35}$ Acknowledging that state regulation of the domestic coca market for non-medical purposes was contrary to its obligations under the drug control conventions, Bolivia had to face many obstacles and limited options to reconcile its national and international legal obligations, including a failed - though formally still pending - attempt to amend the Single Convention. ${ }^{36}$ In the end, as noted above, Bolivia chose to denounce the Single Convention only to re-accede a year later with a reservation regarding the coca leaf. As will be argued below, this could be seen as a precedent for the key question addressed in this article. However, while the procedure resolved the legal conflict surrounding its domestic coca market, as the INCB underscored, the reservation 'is explicitly limited to activities within its territory, thus not conferring and/or broadening any rights to engage in international trade of any kind'. ${ }^{37}$ To legitimise international trade, any country interested in importing the now licitly produced Bolivian coca leaf would first have to go through a similar procedure of denunciation and re-accession with a reservation on coca leaf that would also allow imports. Instead, signing an inter se agreement between Bolivia and those countries could offer a more practicable solution, also making it easier for new countries to join by simply signing up to an already existing agreement.

\section{The permissibility of inter se modification}

\footnotetext{
${ }^{30}$ Ibidem.

${ }^{31}$ Panos Merkouris and Malgosia Fitzmaurice, Re-Shaping Treaties While Balancing Interests of Stability and Change: Critical Issues in the Amendment/Modification/Revision of Treaties, University of Groningen Faculty of Law Research Paper Series, No. 11/2016, November 2015, p. 17.

${ }^{32}$ Uruguayan representative Eduardo Jiménez de Aréchaga, A/CN.4/SR.745 (ILC 1965), op. cit., para 35, p. 150.

${ }^{33}$ Egyptian representative Abdullah El-Erian, A/CN.4/SR.745 (ILC 1965), op. cit., para 53, p. 144.

${ }^{34}$ Ibidem.

${ }^{35}$ Constitution of the Plurinational State of Bolivia, 2009, Article 384: “The State protects the native and ancestral coca as cultural patrimony, as a renewable natural resource of the biodiversity of Bolivia, and as a factor of social unity. In its natural state coca is not a narcotic. The revaluation, production, sale and industrialization of coca shall be governed by law."

https://www.constituteproject.org/constitution/Bolivia_2009.pdf

${ }^{36}$ International Drug Policy Consortium, Bolivia's Legal Reconciliation with the UN Single Convention on Narcotic Drugs, IDPC Advocacy Note, 2011.

${ }^{37}$ INCB, Report of the International Narcotics Control Board for 2017, New York, United Nations (2018), para 145 , p. 32.
} 


\subsection{Specific treaty provisions}

Article 41(a) of the VCLT provides for inter se modification among like-minded parties if 'the possibility of such a modification is provided for by the treaty'. An express provision of this kind illustrates general consent among the parties to further modification among parties. An early example of such a special agreement, article 19 of the 1883 Paris Convention on the Protection of Industrial Property ${ }^{38}$ clarifies that parties reserve the right to make them 'in so far as these agreements do not contravene the provisions of this Convention.' A more recent example, article 311(3) of the 1982 UN Convention on the Law of the Sea (UNCLOS), ${ }^{39}$ provides expressly for inter se agreements modifying or suspending the provisions of the UNCLOS. It states:

Two or more States Parties may conclude agreements modifying or suspending the operation of provisions of this Convention, applicable solely to the relations between them, provided that such agreements do not relate to a provision derogation from which is incompatible with the effective execution of the object and purpose of this Convention, and provided further that such agreements shall not affect the application of the basic principles embodied therein, and that the provisions of such agreements do not affect the enjoyment by other States parties of their rights or the performance of their obligation under the Convention.

Reinforcing the point made earlier about the limited material scope of these inter se agreements, article 311(3) clarifies that such agreements are permitted to modify or suspend the operations of the Convention solely among themselves, without affecting the rights of others. This suggests that derogating modification is limited to provisions of the convention that can be isolated bilaterally without affecting the rights of others. This is reinforced by the repetition in the rest of article 311(3) of the formula in article 41 prohibiting limitation or suspension of a provision the derogation of which is incompatible with the effective execution of the object and purpose of the convention. It suggests that whether such derogating modification is permitted depends on the nature of the provision that is being derogated from by the inter se agreement. To reinforce this point, it can be noted that inter se modifications to the Treaty for the European Union envisaging cooperation in the area of justice were restricted to those that did not undermine the internal market or restrict trade. ${ }^{40}$ The drug conventions do make express provision for modification inter se of certain kinds of provisions, but these provisions are limited to modifications complementing and enhancing the effectiveness of law enforcement measures in the drug conventions such as article 6(11) of the 1988 Trafficking Convention, which provides that the 'Parties shall seek to conclude bilateral and multilateral agreements to carry out or enhance the effectiveness of extradition.'

Where the treaty is silent on this question, VCLT article 41(b) permits modification not expressly provided for by the treaty if 'the modification in question is not prohibited by the treaty', subject to two additional conditions. In order to be permissible these two additional conditions require that the modification (i) does not affect the rights of other parties under the treaty and (ii) 'does not relate to a provision, derogation from which is incompatible with the effective execution of the object and purpose of the treaty as a whole'. There are no specific provisions in the drug conventions prohibiting inter se modification. The question remains whether the drug conventions are to be construed as impliedly prohibiting an inter se modification involving the establishment of a non-medical market for the production and consumption of cannabis. It appears clear from the deliberations in the ILC, however, that it

\footnotetext{
${ }^{38}$ Paris, 20 March 1883 (as further amended), in force 7 July 1884.

${ }^{39}$ Montego Bay, 10 December 1982, 1833 UNTS 3, in force 16 November 1994.

${ }^{40}$ Rigaux and Simon (2011), op. cit., p.1000, referring to Article 43(1) TEU.
} 
that only when a modification failed the second condition one or both of the two additional conditions in article 41(b) could it be considered impliedly prohibited by the convention in question. ${ }^{41}$ It follows that the permissibility of modification is a question of whether an inter se agreement between like-minded states parties with regard to cannabis (or coca) regulation can meet either of the two additional conditions, as both must be met. ${ }^{42}$

\subsection{Affecting the Rights of Other Parties}

Article 41(b) (i) provides that the inter se agreement to modify a treaty is permissible if it "does not affect the enjoyment by the other parties of their rights under the treaty or the performance of their obligations'. The condition is a reflection of the principle res inter alios acta ${ }^{43}$ which runs through article 41 as a whole, based on the fact that the other parties have not consented to the transformation of their rights or obligations. ${ }^{44}$ In essence, this condition is designed to ensure that an inter se agreement to which certain states are not party does not burden them in any way.

The drug conventions set out a complex and extensive range of obligations on states parties. A reservation or inter se agreement among a limited number of parties that would increase the burden on states that were not party to the inter se agreement but which were party to the drug conventions would clearly not be permissible. A question of relevance to this article is whether such a burden on other states would be imposed if one or more parties decide not to prohibit but regulate the sale and supply of cannabis. That is, however, not a question that can be answered in the abstract. It requires proof that the new system of regulation interferes with the other parties' rights or obligations under the treaty. This question will be further explored in sections 6 and 7 below in the context of an analysis of the nature of the drug control treaties and their prohibitive provisions.

\subsection{Compatibility with the Object and Purpose}

Article 41(b) (ii) provides that the inter se agreement is permissible if it 'does not relate to a provision, derogation from which is incompatible with the effective execution of the object and purpose of the treaty as a whole.' The ILC has devoted a lot of attention to defining the concept of the object and purpose of treaties in the context of its in-depth consideration of treaty reservations, and the 'concerns expressed in those debates are not essentially different from concerns that seem relevant also for deciding the permissibility of inter se agreements under article 41 '. ${ }^{45}$ The ILC's $10^{\text {th }}$ report on reservations refers to the opinion of the International Court of Justice that the object and purpose of a treaty can be deduced: 1) from its title; 2) from its preamble; 3 ) from an article placed at the beginning of the treaty that 'must be regarded as fixing an objective, in the light of which the other treaty provisions are to be interpreted and applied'; 4) from an article of the treaty that demonstrates 'the major concern of each

\footnotetext{
${ }^{41}$ Rigaux and Simon (2011), op. cit., p. 994, citing the Report of the ILC to the General Assembly, A/5809, YILC, 1964, Vol. II, p.197. The ILC actually only referred expressly to failure of the second condition in this regard.

42 See Anthony Aust, “Amendment of Treaties”, in: Alexander Orakhelashvili and Sarah Williams, 40 Years of the Vienna Convention on the Law of Treaties (London: BICL 2010), pp. $41 \& 53$.

${ }^{43}$ Res inter alios acta, aliis nec nocet nec prodest, literally 'a thing done between others does not harm or benefit others': the basic principle that a contract or legal agreement cannot affect the rights of non-parties.

${ }^{44}$ Rigaux and Simon (2011), op. cit., p. 1002.

${ }^{45}$ A/CN.4/L.682, Fragmentation of International Law, (ILC 2006), op. cit., para 309, p. 159. Concern with the concept was not unique to treaty modification, but was also essential to the ILC's discussions, for example, of treaty interpretation. See the Third Report on the law of treaties, by Sir Humphrey Waldock, Special Rapporteur, UN Doc A/CN.4/167 and Add.1-3, Yearbook of the International Law Commission, 1964, Vol. 11, p. 52. Indeed, it runs through the whole of the treaty law regime.
} 
contracting party' when it concluded the treaty; 5) from the preparatory work on the treaty; and 6) from its overall framework. Still, on that basis "the Court forms a "general impression", in which intuition and subjectivity inevitably play a large part. ${ }^{46}$ The ILC underscores the difficulties involved in defining the object and purpose of a treaty and concludes: "At most, one can infer that a fairly general approach is required: it is not a question of "dissecting" the treaty in minute detail and examining its provisions one by one, but of extracting the "essence", the overall "mission" of the treaty." 47 This condition is thus not concerned with minor modifications, but with modifications that impact on the raison d'être of the conventions, ${ }^{48}$ on the system as a whole. ${ }^{49}$ Jonas and Saunders point to the difference in wording between articles 41 and the provision on formulation of reservations in article 19 of the Vienna convention on the Law of Treaties:

Article 41 also differs from Article 19 because it contains the words "effective execution" and "as a whole," which may be read as limiting and softening the prohibition. In other words, a modification may permissibly infringe on the object and purpose somewhat, so long as the object and purpose is preserved as a whole. Functionally, a less stringent standard may be justified on the grounds that a modification, which is concluded between only a fraction of states party, is presumably less disruptive than a reservation, which the reserving state makes vis-à-vis all other states party. ${ }^{50}$

The object and purpose of the drug control treaties is primarily laid down firstly in the preamble of the Single Convention which spells out that it is 'Concerned with the health and welfare of mankind', and secondly through the 'general obligation' in article 4 to 'limit exclusively to medical and scientific purposes the production, manufacture, export, import, distribution of, trade in, use and possession of drugs'. ${ }^{51}$ A reservation or inter se agreement that would depart from those basic principles for all the substances controlled under these treaties would clearly not be permissible. The question is, however, whether the effective execution of the object and purpose of the treaty as a whole would be immediately compromised if one or more parties decide not to prohibit but regulate the sale and supply of cannabis for other purposes. This cannot be an abstract question. Interference with other parties' rights can only be established by proof that the inter se agreement results in an infringement of the 'effective execution' of the treaty, and not just a formal infringement which has no concrete effect. Non-parties to the inter se agreement that assert alteration of their rights and obligations must substantiate that claim, mainly because only they have the information relating to the impact of the inter se modification within their territories. To meet the implicit threshold of proof in article 41(1)(b)(i) they will have to show that the inter se modification has a negative impact on their

\footnotetext{
${ }^{46}$ A/CN.4/558/Add.1, Alain Pellet, Special Rapporteur, Tenth report on reservations to treaties, Addendum, (ILC 14 June 2005), para 81-82, p. 11.

${ }^{47}$ Ibid., para 77, p.9. See also Isabelle Buffard and Karl Zemanek, “The 'Object” and 'Purpose' of a Treaty: An Enigma?, Austrian Review of International and European Law, Vol. 3 (1998), p.311 who after charting in considerable detail the incoherence of the concept note at p. 330 that its determination depends on the treaty being interpreted as a whole.

${ }^{48}$ International Court of Justice, Reservations to the Convention on the Prevention and Punishment of the Crime of Genocide, Advisory Opinion, (ICJ 1951), Report 15, p. 21.

${ }^{49}$ WT/DS34/R, WTO Dispute Settlement Panel Report, Turkey-Restrictions on Imports of Textile and Clothing Products, 31 May 1999, para 9, p. 181.

${ }^{50}$ David S Jonas and Thomas N Saunders, "The Object and Purpose of a Treaty: Three Interpretive Methods", in Vanderbilt Journal of Transnational Law, Vol. 43, Issue 3 (2010), p. 565 at p. 575 (footnotes omitted).

${ }^{51}$ The 1988 Convention effectively supplements the 1961 Convention in regard to law enforcement activity, so it is the 1961 Convention which delimits the essential scope of permissible conduct in regard to particular substances. Therefore its object and purpose are largely determinative in this regard, although the object and purpose of the 1971 Convention (see below) is also relevant.
} 
rights or obligations that is actual and not simply theoretical.

\section{The Uncertain Historical Status of Cannabis in the 1961 Convention}

The questions (i) of the rights and obligations of other parties in regard to cannabis and (ii) the object and purpose of the drug conventions in regard to cannabis cannot be adequately dealt with without some sense of the uncertain historical status of the substance within the system. The history of how cannabis came to be subject to control is relevant to the subject matter of this article. The exceptions relative to cannabis cannot be viewed as incompatible with the object and purpose of the conventions since from its inception the system has acknowledged exceptions to the prohibition of cannabis. Cannabis was brought under international control by the 1925 Geneva International Opium Convention and on that basis automatically entered the post-WWII drafting process for the UN Single Convention. Interestingly, with respect to cannabis, the limitation to medical and scientific purposes during this early period only applied to 'Galenical preparations (extract and tincture) of Indian hemp'; and with regard to other purposes, the contracting parties were only required to 'prohibit the export of the resin obtained from Indian hemp and the ordinary preparations of which the resin forms the base (such as hashish, esrar, chiras, djamba) to countries which have prohibited their use' (article 11-a). The system of export authorisation and import certification established under article 12 of the 1925 Convention and administered by the Permanent Central Board (PCB), a precursor body of today's INCB, thus originally included cannabis for non-medical and non-scientific purposes. That also applied to the statistics states parties had to submit annually to the PCB: "estimates of the quantities of each of the substances covered by the Convention to be imported into their territory for internal consumption during the following year for medical, scientific and other purposes' (article 21, emphasis added).

The WHO Expert Committee stated in 1959 that it 'believed that the composition of the schedules should be most carefully reviewed before they become an established part of the new Convention', but this never happened in the case of cannabis and several other substances that were copy-pasted into the Single Convention's draft schedule from the previous treaties. ${ }^{52}$ The scientific basis and even the procedural legality of the inclusion of cannabis in schedules I and IV (reserved for drugs that are 'highly addictive and liable to abuse and rarely used in medical practice ${ }^{53}$ ) is therefore questionable. Recognising that 'cannabis has never been subject to a formal pre-review or critical review', the WHO Expert Committee recommended at its November 2016 meeting to conduct pre-reviews for cannabis and its component substances. ${ }^{54}$

At the time of negotiating the Single Convention, especially in Asia, Africa and the Middle East, cannabis was widely used and socially accepted for cultural, ceremonial and traditional medicinal purposes. The proposal to broaden the phrasing of the treaty's general obligation 'to limit exclusively to medical and scientific purposes' by adding 'and other legitimate purposes' (wording that was used in the 1912 and 1925 treaties), which could have allowed the

\footnotetext{
${ }^{52}$ Esther Danenberg, L.A. Sorge, W. Wieniawski, S. Elliott, L. Amato, W.K. Scholten, "Modernizing methodology for the WHO assessment of substances form the international drug control conventions", in: Drug and Alcohol Dependence, Vol. 131, Issue 3, 1 August 2013, pp. 175-324.

${ }^{53}$ E/CN.7/2014/10, Commission on Narcotic Drugs, Challenges and future work in the review of substances for possible scheduling recommendations: Note by the Secretariat, 18 December 2013, p. 13.

${ }^{54}$ WHO Expert Committee on Drug Dependence, Thirty-eighth report, WHO technical report series no. 1005 , 2017, pp. 35-36.
} 
continuation of some of those centuries-old practices, was rejected ${ }^{55}$ As a compromise, India managed to protect its bhang culture by excluding the leaves of the cannabis plant from the treaty's definition of 'cannabis', and countries with widespread traditional cannabis uses were granted a special 'transitional reservation' option under article 49 to abolish those practices gradually over 25 years. For other reservations, article 50 specified certain restrictions including the procedure that if more than one-third of the parties object it would not be allowed.

Of relevance to the key issue in this report is the fact that the official Commentary on the Single Convention raises the question whether the reservation procedure established under article 50 could in principle be used by parties to reserve the right to allow non-medical uses of cannabis beyond the 25-year limit, and concludes that ' $[\mathrm{b}] \mathrm{y}$ operation of article 50 , paragraph 3 , a Party may reserve the right to permit the non-medical uses as provided in article 49, paragraph 1, of the drugs mentioned therein, ... without being subject to the time limits and restrictions provided for in article $49^{\prime} .56$ Thus, according to the Commentary, unless more than one-third of the treaty parties would object, it could be legitimate for a country to reserve the right to allow non- medical uses of cannabis. It is strongly contended here that, in the absence of specific rules about it in the treaty, in principle the same permissibility would apply to an inter se modification agreement. Objecting Parties might try to argue that the same threshold of objections should apply to inter se modification as well, treating it basically as a 'collective reservation'. However, the threshold for accepting reservations varies across treaties, and the 1988 Trafficking Convention, for example, to which an inter se agreement on cannabis may also need to refer, does not include a procedure for objecting to reservations at all. The VCLT does not specify an objection procedure or threshold for acceptance for inter se modification agreements. The fact that the ILC has argued, as referred to above, that the basic criteria for permissibility of reservations are not 'essentially different' from those of inter se modification, does not imply that treaty-specific objection procedures regarding reservations should be applied in the same way to inter se agreements as well (see the section on Notification and Objections below).

\section{Divergence of control principles under the 1971 Convention}

An additional argument to support the view that the 'integrity' of the UN drug control treaty system would not be immediately compromised if countries make exemptions for cannabis, can be derived from the way in which the 1971 Convention on Psychotropic Substances diverged from the 1961 Convention in regard to certain basic principles of its scheduling system. While 'cannabis' was scheduled as a 'narcotic drug' under the Single Convention, its main psychoactive compound, delta-9-tetrahydrocannabinol (THC) or dronabinol, is included as a 'psychotropic substance' in Schedule II - and several isomers of THC even in Schedule I- of the 1971 Convention. ${ }^{57}$ Diverging from the zero-tolerant principle behind the Single Convention, the 1971 Convention allowed parties to make reservations for plants 'which are traditionally used by certain small, clearly determined groups in magical or religious rites, ... except for the provisions relating to international trade' ${ }^{58}$ Moreover, it included a 'principle of non-acceptance' with regard to all scheduling decisions. A party was permitted to submit a notification explaining why, 'in view of exceptional circumstances, it is not in a position to give

\footnotetext{
${ }^{55}$ David Bewley-Taylor, Tom Blickman and Martin Jelsma, The Rise and Decline of Cannabis Prohibition: The History of Cannabis in the UN Drug Control System and Options for Reform, TNI/GDPO 2014, p. 25.

${ }^{56}$ United Nations, Commentary on the Single Convention on Narcotic Drugs, 1961, New York: 1973, p. 476.

${ }^{57}$ Christopher Hallam, David Bewley-Taylor and Martin Jelsma, Scheduling in the international drug control system, Series on Legislative Reform of Drug Policies No. 25, TNI/IDPC, June 2014, pp. 11-12.

${ }^{58}$ United Nations, Convention on Psychotropic Substances, 1971, Art. 32(4).
} 
effect with respect to that substance to all of the provisions of the Convention'.59

During the 1971 Conference, several developing countries objected to granting parties more 'loopholes' for psychotropic substances 'produced by the industrialized countries' than had been allowed under the 'transitional reservations' for traditional plant-based narcotic drugs of the Single Convention. ${ }^{60}$ India argued that, given the fact that the draft text already made a "provision for review by the Economic and Social Council of decisions taken by the Commission on WHO recommendations, the right of non-acceptance would imply that an individual country could consider itself wiser than those three bodies, which spoke for the international community as a whole', and suggested therefore to introduce a time limit on the right of non-acceptance. ${ }^{61}$ Several Northern countries argued, however, that '[i]nsuperable difficulties could arise' to obtain parliamentary acceptance of the treaty 'unless provision were made in it for a degree of noncompliance with decisions by WHO and the Commission' and that it would be unrealistic to impose 'an arbitrary time limit for a situation of partial compliance' ${ }^{6}{ }^{6}$

The 1971 Conference in the end adopted the right to partial non-compliance for specific substances without time restrictions. The compromise solution envisaged that the nonacceptance of scheduling decisions was circumscribed 'by control measures - graduated according to the various schedules - both national and international, which the non-accepting party should, in any case, apply to a given substance'. ${ }^{63}$ Those measures include the requirement of national licenses for manufacture, trade and distribution, and the provisions relating to international trade specified in articles 12 and 13. Regarding the latter, the nonaccepting State should still '[c]omply with the obligations relating to export and import ... except in respect to another Party having given such notice for the substance in question' ${ }^{64}$

This permitted slippage in obligations tends to undermine the notion of an indissoluble and indestructible object and purpose in the drug conventions. The questionable status of cannabis in the general scheme of the conventions and in particular the failure to assess whether it has analogous qualities to other controlled drugs by the WHO expert committee means that there is a prima facie case that an inter se agreement formalising a shift to an alternative form of regulation for the substance would neither burden the other parties to the drug conventions nor run counter to the object and purpose of the drug conventions. These questions, however, can only be conclusively answered by reference to the nature of the drug conventions.

\section{$6 \quad$ Reciprocal versus absolute treaties}

Whether a contra legem inter se modification affects the rights of other parties, depends in the first place on the basic nature of the treaty, whether it has primarily what Fitzmaurice called 'reciprocal', 'interdependent' or 'integral' characteristics, ${ }^{65}$ or what the ILC study group on the 'Fragmentation of International Law' terms as the 'distinction between treaties containing (merely) reciprocal obligations and treaties whose obligations were non-reciprocal - that is to

\footnotetext{
${ }^{59}$ Ibid., Art. 2(7).

${ }^{60}$ E/CONF.58/7/Add.I, United Nations Conference for the adoption of a Protocol on Psychotropic Substances, Vienna, 11 January - 19 February 1971, Official Records, Volume II, para 4, p. 133 (Liberia).

${ }^{61}$ Ibid, para 2, p.132 (India).

62 Ibid, para 8 (United States), para 11 (Netherlands) and 3 (United Kingdom), p. 133.

${ }^{63}$ E/CONF.58/7/Add.I, op.cit., para 54, p. 181.

${ }^{64}$ United Nations, Convention on Psychotropic Substances, 1971, art. 2(7).

${ }^{65}$ A/CN.4/115, Gerald Fitzmaurice, Special Rapporteur, Third Report on the Law of Treaties, 18 March 1958, Extract from the Yearbook of the International Law Commission: 1958, Vol. II, pp. 27-28.
} 
say, of a 'more absolute type' ${ }^{66}$ For example, the VCLT provides a special rule under article 60 on invoking breach where "the treaty is of such a character that a material breach of its provisions by one party radically changes the position of every other party in respect to the further performance of its obligations under the treaty'. According to Sadat-Akhavi:

A treaty is 'interdependent' when the obligation of each party is dependent on the corresponding performance by all the other parties, so that a fundamental breach by one party prejudices the treaty regime applicable between all parties. For instance, treaties on disarmament and treaties prohibiting the use of particular weapons are 'interdependent' treaties. An inter se agreement modifying the provisions of an 'interdependent' treaty should be unlawful since it necessarily affects the rights of third States under that treaty. ${ }^{67}$

There is more flexibility with regard to treaties 'which are of the reciprocating type, providing for a mutual interchange of benefits between the parties, with rights and obligations for each involving specific treatment at the hands of and towards each of the others individually. ${ }^{68}$ Reciprocal treaties are those in which rights and obligations are granted to other parties to the multilateral convention in a 'quasi- bilateral fashion' and inter se agreements are permissible because the subject matter of those rights - for example, diplomatic relations in the 1961 Vienna Convention on Diplomatic Relations ${ }^{69}$ - means that the impact of a specific change between two parties inter se can be confined to those parties, and has no effect on the rights of others or on the object and purpose of the treaty as a whole. ${ }^{70}$ They are unlike absolute treaties, which as Rigaux and Simon put it, "cannot be reduced to ... bilateral relations, that are malleable à la carte. ${ }^{71}$

The ILC's fragmentation study notes that absolute treaties are often used to unify rules of law in specific domains, to create an 'obligation of solidarity' among the parties, for which conformity with the object and purpose of the treaty serves as a legal test. ${ }^{72}$ Seamless wholes, breach of one rule radically changes the legal position of all other parties. ${ }^{73}$ Justice van Eysinga gave an example in his dissenting decision in the Oscar Chin Case, which involved a question of whether the 1919 Convention of Saint Germain-en-Laye, an inter se agreement, modified the older and much more broadly supported 1885 General Act of Berlin, in regard to the management of the Congo Basin:

The General Act of Berlin does not create a number of contractual relations between a number of States, relations which may be replaced as regards some of these States by other contractual relations; it does not constitute jus dipositivum, but it provides the Congo Basin with a regime, a statute, a constitution. This regime which forms an indivisible whole may be modified, but for this the agreement of all the contracting Powers is required. An inextricable legal tangle would result if, for instance, it were held that the regime of neutralisation provided for in Article 11 of the General Act might be in force for some contracting Powers while it had ceased to operate for certain others. $^{74}$

For Justice van Eysinga, the provision in the Berlin Act for amendment by 'common accord'

\footnotetext{
${ }^{66}$ A/CN.4/L.682, Fragmentation of International Law, (ILC 2006), op. cit., para 310, p. 159.

${ }^{67}$ Seyed Ali Sadat-Akhavi, Methods of Resolving Conflicts between Treaties, (Leiden: Nijhoff, 2003), p. 58.

${ }^{68}$ A/CN.4/115, Third Report on the Law of Treaties, op. cit., p. 27.

${ }^{69}$ Vienna, 18 April 1961, 500 UNTS 95, in force 24 April 1964.

${ }^{70}$ Rigaux and Simon (2011), op. cit., pp. 1003-4.

${ }^{71}$ Rigaux and Simon (2011), op. cit., p. 1004.

${ }^{72}$ A/CN.4/L.682, Fragmentation of International Law, (ILC 2006), op. cit., para 308, p. 159.

${ }^{73}$ VCLT, Article 60(2)(c).

${ }^{74}$ Oscar Chinn case, 12 December 1934, PCIJ, Series A/B, no 63.
} 
reinforced his view. ${ }^{75}$ The effectiveness of absolute treaties depends on compliance with all of its provisions by all of its parties; if two or more parties derogate from one of its provisions they derogate from the treaty as a whole, effecting the legal positions of all of the parties and in consequence impacting on the object and purpose of the treaty. Klabbers notes that plans within the EU, in the late 1990s, to de-activate the Refugee Convention ${ }^{76}$ between Member States of the $\mathrm{EU}^{77}$ ran into criticism that this would result in an impermissible modification between some of the Refugee Convention's parties difficult to reconcile with article 41(1) (b) as it would affect the definition of refugee in article 1 of the Refugee Convention and was incompatible with the effective execution of the Convention's object and purpose.

So the question comes down squarely to this: are the drug conventions of a reciprocal type, permitting inter se variation because their provisions are in their nature 'quasi-bilateral', or are they more integrated or even absolute, where such variation is not permissible because to continue the culinary metaphor the menu is set and cannot be broken up à la carte by parties no longer wishing to eat all of the courses. At first glance the general character of the drug conventions suggests they form an integrated interdependent regime. They satisfy conditions for such absolute treaties identified by Harvard Research in 1935: they have been almost universally subscribed to by states, their provisions have a legislative character, and they have been implemented in a uniform fashion. ${ }^{78}$ It is for that reason they have been identified as constituting a whole and archetypal 'global prohibition regime', ${ }^{79}$ which suggests their rules are integrated and cannot be disassembled by reluctant parties who would defeat their purpose if they entered into an inter se agreement to de-schedule cannabis and permit its non- scientific or non-medical production, supply and use in contravention of article 4 of the 1961 Single Convention.

Digging a little deeper, however, it is arguable that a change in the system of control of cannabis away from strict prohibition would neither lead to a radical change in the position of all of the other parties nor conflict with an entirely unassailable foundational purpose of the drug conventions. The drug conventions do not have the same level of functional obligation as, for example, the International Space Station Intergovernmental Agreement, where the fifteen states parties involved agreed to 'establish a long-term international cooperative framework' for the design, development and operation of an 'integrated International Space Station' to which each participating state agreed to contribute certain 'elements' ${ }^{80}$ An inter se agreement would not be permissible to vary the obligations in the Space Station treaty because it would mean the station would not function. Treaty regimes controlling commodities like the drug conventions are functionally integrated in different degrees in regard to different substances. As described above, both the 1961 Single Convention and the 1971 Convention included provisions allowing parties to exempt themselves - by means of a (transitional) reservation or a notification of non-acceptance-from the control regime for a specific substance under certain circumstances and conditions. On that basis, it could be argued that an inter se

\footnotetext{
${ }^{75}$ Ibid, referring to article 36 of the Berlin Act.

${ }^{76}$ Convention Relating to the Status of Refugees, 28 July 1951, 189 UNTS 150; in force 22 April 1954. See also, article 7 of the ICCPR, the right not to be returned to a country where they may be 'subjected to torture or to cruel, inhuman or degrading treatment or punishment.'

${ }^{77}$ Jan Klabbers, “Treaties - Object and Purpose", in: Max Planck Encylopedia of Public International Law (Oxford: OUP, 2006), para 11.

${ }^{78}$ Draft Convention on the Law of Treaties, Research in International Law under the Auspices of the Faculty of the Harvard Law School, in: American Journal of International Law, Suppl, 1935, vol 29(4), p. 1018.

${ }^{79}$ Ethan Nadelmann, "Global Prohibition Regimes: The Evolution of Norms in International Society”, in: International Organisation (1990), No. 44, pp. 479 and 484.

${ }^{80}$ International Space Station Intergovernmental Agreement, 29 January 1998; in force 27 March 2001; Art. 1.
} 
agreement among a group of countries which seeks a collective exemption from the cannabisspecific provisions of the drug control treaty regime would not be prima facie 'incompatible with the effective execution of the object and purpose of the treaty as a whole' or necessarily affect the rights of other parties.

At a more specific level, if a particular State that is party to an inter se agreement permits a cannabis market for non-medical or scientific purposes it will have an impact of a functional kind - the particular function being domestic suppression of cannabis so as to ensure cannabis does not flow across borders into those that are not party to the inter se agreement stateswhen cannabis actually begins to be trafficked across borders. At that point, the latter states will rightly be able to complain that the former state is in breach of its drug convention obligations because its conduct (in the form of an omission to control the transboundary traffic) will place a burden on the latter states. As Room et al. cautioned in the report of the Global Cannabis Commission:

there will be vociferous opposition from a number of quarters' to any moves to reform and therefore 'it would be wise for a state or states which are moving outside the present conventions to give reassurances that they will continue a commitment to some aspects of the current regime - in particular to controls on international trade which maintain comity, the principle that other states' domestic arrangements, for instance of cannabis prohibition, will be honoured. ${ }^{81}$

To avoid an argument about functional integration being disrupted, the inter se agreement would have to be based on domestic markets that are isolated from non-parties to the inter se agreement. An assumption that a shift to a regulated market among certain states parties would increase the transnational flow of cannabis into states parties not party to the inter se agreement is, however, questionable. The international drug control system is currently ineffective in preventing the international illegal traffic of cannabis in spite of the illegality of this traffic in all states parties. A strictly controlled legal regulated market is likely to prove more effective in preventing the illicit export of cannabis from regulated jurisdictions in comparison to the current situation because state controls over the substance are likely to be tighter and more widely respected than is currently the case, precisely because the states party to the modifying treaty would be operating in an environment of acute awareness of not violating the other parties to the drug conventions rights and obligations (and this would include control of parallel illegal markets). Thus, counter intuitively, a legally regulated market in parties to the inter se agreement may well benefit non-parties to the agreement instead of harming them.

\section{The ‘Absolute’ Nature of Prohibition}

The drug conventions do require a certain degree of normative integration in order to achieve their overall functional purposes. This is revealed through internal elements of the treaty such as statements about the need for 'universal action' in paragraph three of the preamble to the Single Convention, and through external state practice such as the reiteration in GAResolutions that there is a duty to implement 'as a matter of priority, all the provisions' of the drug control conventions, ${ }^{82}$ and a 'collective responsibility to uphold the principles of human dignity,

\footnotetext{
${ }^{81}$ Robin Room, Benedikt Fischer, Wayne Hall, Simon Lenton, Peter Reuter and Amanda Feilding (convener), Cannabis Policy: Moving Beyond Stalemate, The Global Cannabis Commission Report, Beckley Foundation/Oxford University Press, September 2008, pp. 167-168.

${ }^{82} \mathrm{~A} / \mathrm{RES} / 72 / 198$, International cooperation to address and counter the world drug problem, 29 January 2018, Resolution adopted by the General Assembly on 19 December 2017, paragraph 93.
} 
equality and equity at the global level'. ${ }^{83}$ It is much more difficult to sustain the notion that this level of normative integration implies that the drug conventions have established a system where states have rights in regard to the conduct of other states in regard to specific drugs within their own domain, even if it does not have a direct cross-border effect. Prior to 1961 the drug control system was interpreted in such a way as to respect differences between the laws of the state parties. The system functioned to prevent the uncontrolled export of certain substances to states that have prohibited those substances. ${ }^{84}$ This tolerance of difference was fundamental to the origins of the international control system prior to 1946, until a transformation of the system was undertaken in the post-War period which culminated in the 1961 Convention. It involved the attempt to convert what had been essentially a 'reciprocal' system into a morally charged 'absolute' principle of prohibition.

This transformation never achieved that goal. ${ }^{85}$ The drug conventions are integrated to a degree, but not so integrated that they consist of an absolute normative regime akin to, for example, that created in regard to prohibition of genocide by the Genocide Convention of $1949 .{ }^{86}$ They have neither achieved ius cogens status nor are they part of customary international law. ${ }^{87}$ To qualify as a ius cogens rule absolute prohibition would first have to qualify as a norm of general international law (i.e. a rule of customary international law) and second be recognized by the international community as a whole as a rule from which no derogation is permitted. ${ }^{88}$ There is no evidence in state practice and opinio iuris that it has achieved even the status of customary international law, never mind made it into the ranks of the elite sub-set of rules of custom that qualify as ius cogens. There is no-evidence from current states parties to the Single convention that they consider the foundational provision of treaty-based prohibition, article 4(c) of the Single convention, is anything more than a treaty obligation. In particular given that most states are parties to the Single Convention, there is no evidence of non-parties acknowledging that independent of any treaty provision, the limitation to scientific and medical purposes is a norm by which they are bound as a matter of customary international law. Nor is there any practice to substantiate a claim that the international community of states as a whole must recognise and accept that article 4(c) cannot be derogated from. There is no practice to suggest they have always considered that article 4(c) will remain immutable and never subject to repeal. On the similarly fundamental question of whether drug trafficking was contrary to the purposes of the UN, the Canadian Supreme Court answered in the negative. ${ }^{89}$ And finally, the 1961 Convention

\footnotetext{
${ }^{83}$ A/RES/55/2, United Nations Millenium Declaration, Resolution adopted by the General Assembly, 8 September 2000. The Declaration reiterates this common duty in para 2 and then later mentions the need to redouble efforts to 'counter the world drug problem' in para 9.

${ }^{84}$ See the account given of the history of the system in: E/INCB/W.22, The Genesis of International Control of cannabis - 1912 to 1978, International Narcotics Control Board, Twenty-third session, 12 May 1978; and Hamilton Wright, “The International Opium Conference”, in: American Journal of International Law, Vol. 7 , No. 1 (January 1913), pp. 108-139.

${ }^{85}$ See David Bewley-Taylor and Martin Jelsma, "Regime change: Re-visiting the 1961 Single Convention on Narcotic Drugs", in: International Journal of Drug Policy, Vol. 23, No. 1 (January 2012), pp. 72-81.

${ }^{86}$ Reservations to the Convention on the Prevention and Punishment of the Crime of Genocide, International Court of Justice, Advisory Opinion, 1951 I.C.J. 15.

${ }^{87}$ P.H.P.H.M.C. (Piet Hein) van Kempen and Masha Federova, International Recht en Cannabis II, Regulering van cannabisteelt en -handel voor recreatief gebruik: positieve mensenrechtenverplichtingen versus VN-drugsverdragen (Deventer: Kluwer, 2016), p. 264. Sir Gerald Fitzmaurice recognised in his Third Report on the Law of Treaties, A/CN/4/115 (1958), para 29, p. 30, that states may depart from a rule in a treaty through an inter se agreement unless it is in the nature of a ius cogens rule.

${ }^{88}$ A/CN.4/706, International Law Commission, Second report on jus cogens by Dire Tladi, Special Rapporteur, 16 March 2017, para 43, pp. 21-22.

${ }^{89}$ Pushpanathan v Canada (Minister of Citizenship and Immigration), 1 SCR 98, ILDC 182 (CA 1998), paras 64, 69, 72.
} 
itself contains provisions for amendment and there is no specific restriction made in regard to article 4(c).

It is also not plausible to argue that the rules underpinning absolute prohibition are erga omnes obligations, which the international community as a whole are required to observe, as is the case with human rights conventions. ${ }^{90}$ With regard to erga omnes obligations, non-injured States may be entitled to invoke a breach, according to the ILC, because the "collective interest of treaty parties has been violated". ${ }^{91}$ The drug conventions, however, do not meet the erga omnes criteria; failure to adhere to their obligations does not necessarily have consequences for all other parties, it will depend on the circumstances. Interestingly, there is also no specific procedure in the conventions for the making of complaints by states that are not directly affected. ${ }^{92}$

It is thus untenable to argue that a government regulated market in cannabis comes close to violate a ius cogens or erga omnes norm and is therefore ipso facto in violation of the rights of the other parties, unlike inter se modification of a human rights convention which would result in a violation of an absolute regime. As a practical matter, states that object to an inter se agreement may contest the degree of integration of the global drug control system, but the onus would be on them to show that the system was integrated in an absolute manner in regard to the particular substance in question.

Looking more closely at the nature of the obligations in the regime in regard to particular substances, the UN drug control regime applies to a specific set of substances listed on the treaty schedules, which are subject to exemptions, varying levels of control, review procedures and regular changes. Early scheduling decisions, especially on cannabis, coca and opium, have often been criticised for being influenced by colonial heritage, cultural and racial prejudices, and ideology more than scientific evidence. ${ }^{93}$ Many other psychoactive substances, including harmful ones like alcohol and tobacco, have never been placed under international control at all, or - in the case of tobacco- under a fundamentally different control regime of a more regulatory than prohibitive nature. ${ }^{94}$ It is therefore difficult to argue that the UN drug control treaty regime somehow embodies an 'absolute' prohibition principle based on a universal and unexceptionable policy goal of limiting all psychoactive drugs exclusively to medical and scientific purposes, comparable to, for example, the absolute nature of the prohibition of torture under international law from which derogation by means of reservation or inter se modification obviously would not be permissible.

\section{$8 \quad$ Precedents and Practices}

\subsection{The 1925 and 1931 'closed agreements'}

Examples of inter se agreements that have raised issues about compatibility with previous drug

\footnotetext{
${ }^{90}$ P.H.P.H.M.C. (Piet Hein) van Kempen and Masha Federova, International Recht en Cannabis II (2016), op. cit., pp. 254-259.

${ }^{91}$ A/CN.4/L.682, Fragmentation of International Law, (ILC 2006), op. cit., para 393, p. 199.

${ }^{92}$ P.H.P.H.M.C. (Piet Hein) van Kempen and Masha Federova, International Recht en Cannabis II (2016), op. cit., pp. 267-268.

${ }^{93}$ David Bewley-Taylor, Tom Blickman and Martin Jelsma, The Rise and Decline of Cannabis Prohibition (2014), op. cit., pp. 8-31; and Mario Argandoña, Anthony Henman, Ximena Echeverría, Pien Metaal, Martin Jelsma, Ricardo Soberón, Coca Yes, Cocaine No? Legal options for the coca leaf, TNI Drugs \& Conflict Debate Paper 13, Amsterdam: May 2006, pp. 4-9.

94 WHO Framework Convention on Tobacco Control, adopted by the World Health Assembly on 21 May 2003, in force February 2005.
} 
control treaties are rare. One potential example involves the continued reliance during the League era of states that produced opium on regulated markets when other states wished to proceed to total prohibition for non- medical purposes. Article 2 of the 1925 Geneva International Opium Convention ${ }^{95}$ obliged parties to undertake to enact law for the effective control of the production of opium. In spite of this promise made to other states parties to the 1925 Convention, opium producer states opted to rely on government monopolies to control production, and this approach was formalised in two 'closed agreements', the 1925 Agreement Concerning the Suppression of the Manufacture of, Internal Trade in, and Use of, Prepared Opium, ${ }^{96}$ and the 1931 Agreement Concerning the Suppression of Opium Smoking ${ }^{97}$ which were limited to the opium producer states 'which still recognise the use of prepared opium', at the time largely under colonial rule. ${ }^{98}$

Whether the special agreements were a true inter se modification is difficult to say. The 1925 Special Agreement preceded the 1925 Geneva Convention, but the U.S. and some others regarded it as an agreement contrary to the overall purpose of the 1912 The Hague Opium Convention. It led to the U.S. and China walking out of the negotiations of the 1925 Geneva Convention, arguing that ' $[\mathrm{t}]$ here is no likelihood under present conditions that the production of raw opium and coca leaves will be restricted to the medicinal and scientific needs of the world' ${ }^{99}$ In the 1931 Agreement, Britain, France, India, Japan, the Netherlands, Portugal and Siam (now Thailand) 'decided to review the position in regard to the application in their FarEastern possessions and territories' of the earlier instruments and agreed to 'supplement' them with a number of measures between themselves alone. ${ }^{100}$ The starting point for the 1931 Conference were the recommendations of the Commission of Enquiry into the Control of Opium Smoking in the Far East, which included suggestions for a revision of some of the provisions of the 1912 Opium Convention and the 1925 Geneva Opium Agreement:

The Commission had never imagined that the stipulations of either international or municipal law held good for ever. They were quite aware that many of their recommendations necessitated changes in international conventions or agreements and in the national systems of law; but they had not hesitated on that account to put them forward, for they were convinced that certain changes were necessary if progress was to be made. ${ }^{101}$

The 1925 Geneva Convention represented a political compromise in the sense that its article 5 obligation to 'enact effective laws or regulations to limit exclusively to medical and scientific purposes the manufacture, import, sale, distribution, export and use' of 'manufactured drugs' had been limited in the case of opium to 'medicinal opium' only, defined in article I to mean 'raw opium which has undergone the processes necessary to adapt it for medicinal use in accordance with the requirements of the national pharmacopoeia'. With regard to other opium products, the contracting parties of the 1931 Agreement agreed that 'retail sale and distribution of opium shall take place only from Government shops ... or from shops managed, under Government supervision'; a provision which 'need not be applied if a system of licensing and

\footnotetext{
${ }^{95}$ Geneva, 19 February 1925, 81 LNTS 317, in force September 1928.

${ }^{96}$ Geneva, 11 February, 1925, 51 LNTS 337, in force July 1926.

${ }^{97}$ Bangkok, 27 November 1931, 177 LNTS 373, in force April 1937.

${ }^{98}$ Quincy Wright, "The Opium Question”, in: American Journal of International Law, Vol. 18, No. 2 (April 1924). pp. 281-295.

${ }^{99}$ Quincy Wright, “The Opium Conferences”, in: American Journal of International Law, Vol. 19, No. 3 (July 1925), p. 561.

${ }^{100}$ Bangkok, 27 November 1931, 177 LNTS 373, in force April 1937, pp. 2-3.

${ }^{101}$ C.577.M.284.1932.XI, League of Nations, Conference on the Suppression of Opium-Smoking Convened Under Article XII of the Geneva Opium Agreement, 1925, Bangkok, November 9th to 27th, 1931, Minutes of the Meetings and Documents Submitted to the Conference, Geneva, August 1932, p. 97.
} 
rationing of smokers is in force, which affords equivalent or more effective guarantees' (article I) and that '[p]ersons under twenty-one years of age shall be prohibited from smoking opium and from entering any smoking-establishment' (article II). The parties furthermore derogated from certain earlier restrictions on international trade by agreeing that 'it shall be permissible for a Government Monopoly to be supplied with prepared opium from the factory of a Government Monopoly in another territory of the same Power' (article IV). There is thus an argument that the 1931 Agreement clashed with a number of provisions of the 1925 Geneva Convention, and could be seen as an early example of an inter se modification agreement to loosen certain drug control treaty obligations for a group of states parties.

\subsection{The Bolivian reservation on coca leaf}

Bolivia's successful attempt to derogate from its drug control treaty obligations regarding the coca leaf serves if not as a strict precedent of an inter se agreement then at least as an analogous challenge to the drug conventions in regard to the level of control over a specific substance. After a failed attempt to amend the Single Convention's Article 49, which obliges parties to abolish coca leaf chewing within 25 years, in June 2011 Bolivia became the first country to denounce the treaty, re-acceding early 2013 with the following reservation:

The Plurinational State of Bolivia reserves the right to allow in its territory: traditional coca leaf chewing, the consumption and use of the coca leaf in its natural state; for cultural and medicinal purposes; for its use in infusions, and also the cultivation, trade and possession of the coca leaf to the extent necessary for these licit purposes. At the same time, the Plurinational State of Bolivia will continue to take all necessary measures to control the cultivation of coca in order to prevent its abuse and the illicit production of the narcotic drugs which may be extracted from the leaf. ${ }^{102}$

Despite a call from the INCB arguing that Bolivia's move 'would undermine the integrity of the global drug control system', ${ }^{103}$ the number of objections fell far short of the one- third of treaty parties (62) required to block it. The objections to Bolivia's reservation came primarily from G8 and EU countries. ${ }^{104}$ According to Arp, objection only from a selective group may suggest that a denunciation and re- accession with a reservation cannot be seen as contrary to internationally accepted norms of customary law: 'For most other states, such a practice seems to be an acceptable procedure to formulate a late reservation to a treaty. At least these states' silence when faced with such a situation - as notably in the Bolivian example - implies their acquiescence.' ${ }^{105}$ Arp also notes that '[t] he corpus of international treaty law adopted after

\footnotetext{
102 This is a corrected translation from Bolivia's original notification in Spanish. The two different versions of the official English translation available in the UN treaty depository both contain minor but legally relevant mistakes, see C.N.829.2011.TREATIES-28 (Depositary Notification), Bolivia (Plurinational State of): Communication (10 January 2012). The original Spanish text as submitted by Bolivia reads: 'El Estado Plurinacional de Bolivia, se reserva el derecho de permitir en su territorio la masticación tradicional de la Hoja de Coca, el consumo y el uso de la Hoja de Coca en su estado natural; para fines culturales y medicinales; como su uso en infusión, así como también el cultivo, el comercio y la posesión de la Hoja de Coca en la extensión necesaria para estos propósitos lícitos. Al mismo tiempo, el Estado Plurinacional de Bolivia seguirá tomando todas las medidas necesarias para controlar el cultivo de Coca para prevenir su abuso y la producción ilícita de estupefacientes que pueden extraerse de las hojas.'

${ }^{103}$ UNIS/NAR/1114, International Narcotics Control Board Regrets Bolivia's Denunciation of the Single Convention on Narcotic Drugs, UN Information Service, press release (5 July 2011).

${ }^{104}$ TNI/WOLA, Bolivia wins a rightful victory on the coca leaf - Creates a positive example for modernizing the UN drug conventions, press release (11 January 2013). The G-8 countries (United States, France, Germany, Italy, Japan, United Kingdom, Canada and the Russian Federation) plus Sweden, the Netherlands, Portugal, Finland, Israel, Ireland, and Mexico objected to Bolivia's reservation.

${ }^{105}$ Björn Arp, "Denunciation Followed by Re-Accession with Reservations to a Treaty: A Critical Appraisal of Contemporary State Practice", in: Netherlands International Law Review, Volume 61, Issue 2 (June 2014), p.
} 
World War II is aging, and seldom do those treaties provide for flexible procedures to adapt to new circumstances'. ${ }^{106}$ After analysing five recent cases involving different unrelated treaty regimes, he goes on to argue that in some circumstances the acceptability of the controversial procedure increases in times of normative change:

The European states seem not to oppose the denunciation and re-accession with a reservation when this forms part of a broader process of the reform and change of international law. The Swedish exampleshows that no state objects to the denunciation and re-accession with a reservation if the interested states were already critical about the existing treaty rules that were affected by the reservation. ${ }^{107}$

The Bolivian derogation from certain treaty obligations regarding the coca leaf does not appear to have affected the rights of other parties in any serious way. Other examples like khat, kratom and ephedra, psychoactive plants with stimulant properties comparable to coca, which are not controlled under the international drugs conventions but are subjected to widely varying degrees of national controls and prohibitions, provide further evidence for the possibility of co-existence in practice of fundamentally different control regimes for the same substance. In the case of cannabis, the early stages of 'soft defection' did lead to diplomatic tensions, for example between the Netherlands and neighbouring countries, but the rapidly expanding divergence in cannabis policies at national and sub-national levels, including the fully legally regulated markets in U.S. states and Uruguay, have thus far not caused major problems with neighbouring jurisdictions that maintain a prohibitionist approach.

The fact that in the Bolivian case none of the objecting states considered the reservation to be an obstacle for the re-entry into force of the Convention between them and Bolivia ${ }^{108}$ could be interpreted as a tacit agreement that treaty provisions regarding specific substances are in principle 'separable from the remainder of the treaty with regard to their application'. ${ }^{109}$ And, as noted above, the rules applicable to reservations are in principle the same as those for a collective derogation from certain treaty obligations by means of an inter se modification agreement.

\subsection{UN Convention on the Law of the Sea}

Analogous instruments to inter se agreements that appear to conflict with the terms of the original convention can be found in other areas of law. Perhaps the most famous is the 1994 Agreement Relating to the Implementation of Part XI of the UN Convention on the Law of the Sea (the 'Deep Sea Bed Agreement', UNCLOS), ${ }^{110}$ used to coax Western states into supporting the UNCLOS which was not yet in force even though the Agreement appeared to contradict the provisions of the UNCLOS in regard to the mining of the deep sea bed, which in effect the Agreement amended. ${ }^{111}$ Participants in the informal consultations, however, rejected the idea of

164.

106 Ibid., p. 145.

107 Ibid., p. 164.

${ }^{108}$ See for example C.N.361.2012.TREATIES-VI.18 (Depositary Notification), United States of America:

Objection to the Reservation Contained in the Communication by the Plurinational State of Bolivia (3 July

2012): 'Should Bolivia's reservation be deemed to be permitted in accordance with Article 50, paragraph 3 of

the Convention, this objection would not constitute an obstacle to the entry into force of the Convention

between the United States and Bolivia, but the United States would not assume toward Bolivia any legal obligation under the Convention that is affected by the reservation' (most other objecting states used similar wording).

${ }^{109}$ VCLT, Separability of treaty provisions, Article 44.

${ }^{110}$ Adopted by the General Assembly on 28 July 1994, 1836 UNTS 42, in force 1996.

${ }^{111}$ Anthony Aust, Amendment of Treaties (2010), op. cit., pp. 41 and 53. 
a protocol of amendment, preferring the label of an 'implementation agreement'. According to Harrison, '[w] hilst many of the basic principles underlying the deep seabed mining regime remain the same, the detailed provisions are the subject of far-reaching reform. The language of the Agreement is straightforward and uncompromising. Several provisions of the Convention are simply "disapplied". ${ }^{112}$ States not yet party to UNCLOS had to become party to the Agreement and the main treaty which it contradicted, while states already party to UNCLOS have been taken to have acquiesced in this 'imaginative' route towards maintaining universal participation in the law of the sea. Formally, however, with regard to states which became party to the Convention prior to the adoption of the Agreement, it is only binding on those that have accepted it, and there are a number of UNCLOS parties - some 35-for which the 1994 Agreement is not yet law. ${ }^{113}$ In similar fashion an inter se agreement on cannabis regulation which deviates from strict prohibition can be rationalised on the basis of maintaining universal subscription to the principal elements of the international drug control system, while allowing parties to 'disapply' the implementation of certain provisions.

\section{$9 \quad$ Notification and Objections}

'It is generally assumed,' according to the ILC, 'that participation in a multilateral treaty creates a community of interests and a solidarity implying an entitlement for the parties to express their views on the compatibility of special arrangements concluded between some of them with the overall regime of the treaty. ${ }^{114}$ Article 41(2) of the VCLT provides therefore for a duty on those parties intending to enter such an inter se agreement to notify the other parties to the drug conventions and of the particular modification for which the inter se agreement provides. It makes it clear that compliance with article 41 must be ensured before such a treaty is entered into as the simple act of notification in time of their precise intentions (which should be worked out by that point) serves as a warning and conveys the content of the proposed changes allowing due diligence in this regard by the other parties who may if they feel it necessary voice their objections. ${ }^{115}$ However, it is not necessary to do so at an early stage:

The Commission considered that it is unnecessary and even inadvisable to require notice to be given while a proposal is merely germinating and still at an exploratory stage. It therefore expressed the requirement in terms of notifying their "intention to conclude the agreement and ... the modifications to the treaty for which it provides" in order to indicate that it is only when a negotiation of an inter se agreement has reached a mature stage that notification need be given to the other parties. ${ }^{116}$

The ILC study group on the 'Fragmentation of International Law' dealt in considerable detail with the inter se issue, and confirmed that 'notification must be given at a relatively advanced stage in the negotiation of the inter se agreement but nevertheless sufficiently prior to its conclusion so as to enable a meaningful reaction'. ${ }^{117}$ It is for each other party to make up their mind whether the inter se agreement breaches the general agreement. ${ }^{118}$ However, the legal effect of an objection made after notification is uncertain; 'it seems clear that the inter se agreement

\footnotetext{
112 James Harrison, Evolution of the law of the sea: developments in law-making in the wake of the 1982 Law of the Sea Convention, School of Law, University of Edinburgh (5 July 2007), p. 99.

${ }^{113}$ Ibid., pp. 100-101.

${ }^{114}$ A/CN.4/L.682, Fragmentation of International Law (ILC 2006), op. cit., para 307, p. 158.

115 Rigaux and Simon (2011), op. cit., pp. 989 and 1006-7.

116 Arthur Watts (ed.), The International Law Commission, 1949-1998: The Treaties, Oxford University Press 1999, p. 717.

117 A/CN.4/L.682, Fragmentation of International Law (ILC 2006), op. cit., para 318, p. 164.

${ }^{118}$ Ibid., para 313, p. 161, relying on the Reservations opinion, I.C.J. Reports 1951, p. 26.
} 
concluded in deviation from the original agreement is not thereby invalidated', it depends on an interpretation of the original treaty as to what consequences should follow. ${ }^{119}$

The procedural requirement of notification at such a late stage, means that the States who are germinating the inter se agreement are placed in the strategically fortunate position of being able to iron out the nature of their agreement, before bringing it officially to the notice of other parties to the prior agreement. In result, objectors from outside the group cannot disrupt the process before it is settled.

Inter se modification is not akin to amendment of the general body of the treaty 'as between all parties', governed by article 40 of the VCLT, precisely because not all the parties participate. It permits modification among a restricted group of parties so long as the rights and obligations of the whole group under the treaty are respected. If its terms are not observed, conclusion of an inter se agreement may lead to accusations of breach of the drug conventions triggering state responsibility, but that is not the main concern here. Firstly because, as the Bolivian example has shown, even if some other parties agree a material breach has occurred and the integrity of the treaty is compromised, a response of termination of the treaty by those states that consider their rights affected is highly unlikely because that would only further erode the effective implementation of the treaty they intend to protect, so would not be in their interest. And secondly because the reality is that the rapidly changing drug policy landscape has already led to treaty breaches and those are only likely to increase; the inter se modification would not be the cause of the breach, but rather an attempt to reconcile under international law breaches that are already happening in practice.

\section{Concluding Reflections}

Reaching a new global consensus to revise or amend the UN drug control conventions in order to accommodate legally regulated markets for cannabis, coca or other psychoactive plants and substances controlled under these treaties, does not appear to be a viable political scenario for the short-term foreseeable future. The inability to reach global consensus is not limited to drug control; it is a dilemma that links drug control with other global issues where global consensus is breaking down. ${ }^{120}$ Meanwhile, the limits of flexible treaty interpretations have been reached and overstretching them any further with legally dubious arguments would result in undermining basic principles of international law. ${ }^{121}$ States that intend to move towards legal regulation, or that have already done so, are therefore obliged to explore other options to reconcile such policy changes with their obligations under international law. Only a few options are available that do not require the consent of all the treaty parties. ${ }^{122}$

The WHO can recommend after a critical review by its Expert Committee on Drug Dependence (ECDD) to 'un-schedule' a controlled substance (remove it from the treaty schedules), and the Commission on Narcotic Drugs can adopt the recommendation by a simple or two-thirds majority vote (for the 1961 and 1971 conventions respectively). As noted above, the WHO

\footnotetext{
${ }^{119}$ Ibid., para 319, p. 164.

${ }^{120}$ See, for example, Kevin Rudd, "Wresting Order from Chaos”, in: The World Today, Vol. 71, No. 3 (JuneJuly 2015), pp. 14-15.

${ }^{121}$ Robert C. Zitt, "Should I Stay or Should I Go?: Why Bolivian Tactics and U.S. "Flexibility" Undermine the Single Convention on Narcotic Drugs", in: Brooklyn Journal of International Law, No. 42 (2016), p. 525.

${ }^{122}$ David Bewley-Taylor, Martin Jelsma and Steve Rolles, Cannabis Regulation and the UN Drug TreatiesStrategies for Reform, Briefing Paper, WOLA/TNI/GDPO/MUCD/HRDP/CDPC/Canadian HIVAIDS Legal Network (June 2016), pp 9-13.
} 
Expert Committee is in fact undertaking a review process for cannabis and a special ECDD meeting to discuss pre-reviews of cannabis-related substances took place in June $2018 .{ }^{123}$ The outcome of the subsequent critical review could come to the CND agenda earliest by March 2019 and will probably result in its deletion from Schedule 4, and possibly to a de-scheduling from Schedule 1 to 2 . It is, however, unlikely under current political circumstances that a WHO recommendation to delete all cannabis-related substances from the treaty schedules altogether would get the required CND majority.

The only other available options that do not require consensus are either unilaterally by late reservations or denunciation and re- accession with new reservations, or collectively by inter se modification agreements among like-minded countries. All of these options are controversial because a generalized application of such procedures would erode the stability of international treaty regimes. Recourse to these options for the purpose of legitimising cannabis regulation will be contested, as was the case with Bolivia's procedure which — in the end successfullylegitimised the legal regulation of its domestic coca market.

Nevertheless, applied with caution and reason under exceptional circumstances, inter se treaty modification appears to provide a useful safety valve for collective action to adjust a treaty regime frozen in time such as the UN drug control conventions, even when potentially the majority of states might still be supportive of continued prohibition. ${ }^{124}$ It would require that the like-minded agreement includes a clear commitment to the original treaty aim to promote the health and welfare of humankind and to the original treaty obligations vis-à-vis countries not party to the inter se agreement. Few other routes are available that could allow more manoeuvring within the treaty regime while avoiding the cumbersome process of unanimous approval; under such circumstances, as Klabbers notes, the inter se option is 'perhaps the most elegant way out'. ${ }^{125}$ The specific advantages of adopting an inter se agreement in regard to cannabis are:

- It could provide a model that respects international law while moving beyond dubious flexibility arguments that have negative implications for the integrity of international law beyond drug control.

- It could provide a basis for an alternative group response to the current control model, serving as a focus point for states parties to the drug control regime that are struggling to apply the current prohibitive model and seeking a more promising alternative.

- It would signal the intention of the parties to the inter se agreement to permanently change their system of regulation of cannabis and their relationship with the UN drug control regime.

- It would recognise that cannabis policy trends have moved beyond the realms of treaty flexibility and that today's political realities and limitations of the UN drug policy making mechanisms present obstacles for treaty amendments or other scenarios for a consensusdriven evolution of the UN drug control treaty regime.

\footnotetext{
${ }^{123}$ E/CN.7/2016/CRP.13, Extract from the Report of the 38th Expert Committee on Drug Dependence, convened from 14 to 18 November 2016, at WHO headquarters in Geneva, 30 November 2016, p. 7.

${ }^{124}$ David Bewley-Taylor and Malgosia Fitzmaurice, The Modernization of Treaty Regimes: The Contrasting Cases of International Drug Control and Environmental Regulation, Working/Draft Paper, Expert Seminar on Cannabis Regulation and the UN Drug Control Treaties (Amsterdam: 26-28 October, 2017).

125 Jan Klabbers, “Treaties, Amendment and Revision,” in: Max Planck Encyclopedia of Public International Law (December 2006), p. 1086.
} 
- It would provide a framework for a more principled compliance with the underlying goal and purpose of the conventions, prioritising respect for human rights, health care and crime prevention.

- It would provide opportunities to experiment and learn from different models of regulation.

- It would open the possibility of international trade, enabling small cannabis farmers in traditional Southern producing countries to start producing for the regulated licit markets. Closed national systems are unlikely to fully replace existing illicit markets that are partly dependent on international trade to accommodate product variety and quality, cultural diversity and consumer preferences. Alternative development schemes aiming to shift cannabis farmers to other products have failed; the only viable option is to involve them in the opening licit cannabis markets for medicinal and other uses.

The possibility of inter se modification was specifically designed to find a balance between the stability of treaty regimes and the necessity of change in absence of consensus in order to respond to the social conditions in certain like-minded states. The circumstances in which the UN drug control treaty regime finds itself today-systemic challenges and inconsistencies, increasing tensions with State practices, huge political and procedural obstacles to amendments, and unilateral escape attempts - merit a careful consideration of the legitimacy of its application. A coordinated collective response has clear benefits compared to a chaotic scenario of a growing number of different unilateral reservations and questionable reinterpretations. Indeed, inter se modification would facilitate the development of what, within an international policy environment characterized by faux consensus, is increasingly necessary: a 'multi- speed drug control system'126 operating within the boundaries of international law, rather than one that strains against them. It could also include a mechanism such as a Conference of the inter se Parties (COISP) to regularly review the agreements and enable further evolution based on lessons learned, and in particular to prevent violation of the rights of the other parties in the principal conventions.

\section{Acknowledgments}

This paper benefitted greatly from the detailed feedback of participants at the Expert Seminar 'Cannabis Regulation and the UN Drug Control Treaties', organized by the Transnational Institute (TNI), the Global Drug Policy Observatory (GDPO) and the Washington Office on Latin America (WOLA), Amsterdam, 26-28 October 2017, where the authors presented an initial draft version for discussion. As is the norm, any errors of fact or interpretation remain with the authors.

\footnotetext{
${ }^{126}$ Neil Boister. "Waltzing on the Vienna Consensus on Drug Control? Tensions in the International System for the Control of Drugs", in: Leiden Journal of International Law, Vol. 29, Issue 2 (2016), p. 409.
} 